\title{
The Effectiveness of Induced Defense Responses in a Susceptible Potato Genotype Depends on the Growth Rate of Phytophthora infestans
}

\author{
Cécile Thomas, ${ }^{1}$ Romain Mabon, ${ }^{1}$ Didier Andrivon, ${ }^{1}$ and Florence $\mathrm{Val}^{2, \dagger}$ \\ ${ }^{1}$ INRA, UMR IGEPP 1349, Institut de Génétique, Environnement et Protection des Plantes, Domaine de la Motte au Vicomte, BP \\ 35327, 35653 Le Rheu Cedex, France; and ${ }^{2}$ Agrocampus Ouest, UMR IGEPP 1349, Institut de Génétique, Environnement et \\ Protection des Plantes, 65, rue de Saint-Brieuc, 35042 Rennes Cedex, France
}

Accepted 21 July 2018.

\begin{abstract}
Phytophthora infestans causes the devastating potato late blight disease, which is widely controlled with fungicides. However, the debate about chemical control is fueling a promotion toward alternative methods. In this context, the enhancement of natural plant immunity could be a strategy for more sustainable protection. We previously demonstrated that a concentrated culture filtrate (CCF) of $P$. infestans primes defense reactions in potato. They are genotype-dependent and metabolites produced decrease pathogen growth in vitro but not in vivo on tubers. Induced potato defenses are assumed to affect $P$. infestans life history traits depending on strains. This assumption was studied in vivo through induced leaflets on a susceptible genotype inoculated with four $P$. infestans strains differing for lesion growth rate. This study combines both defenses mechanistic analysis and ecological observations. Defense-gene expressions were thus assessed by quantitative reverse transcription-polymerase chain reaction; pathogen development was simultaneously evaluated by measuring necrosis, quantifying mycelial DNA, and counting sporangia. The results showed that $\mathrm{CCF}$ pretreatment reduced the pathogenicity differences between slow- and fast-growing strains. Moreover, after elicitation, PR-1, PR-4, PAL, POX, and THT induction was strain-dependent. These results suggest that $P$. infestans could develop different strategies to overcome plant defenses and should be considered in biocontrol and epidemic management of late blight.
\end{abstract}

Phytophthora infestans (Mont.) de Bary causes late blight, the main disease of potato (Solanum tuberosum L.) (Fry 2008; Gyetvai et al. 2012). Recent estimates value global late blight losses and control at $\$ 6.7$ billion a year (Haas et al. 2009). Late blight control currently relies on frequent applications of protectant or systemic fungicides (Haverkort et al. 2009).

Given the adverse effects of such prolonged and intensive pesticide use, alternative methods are now increasingly promoted. They rely mostly on the deployment of genetic resistance, coupled with biological and cultural control measures

${ }^{\dagger}$ Corresponding author: Florence Val;

E-mail: florence.val@agrocampus-ouest.fr

Funding: $\mathrm{C}$. Thomas was supported by an industrial convention on training through research (CIFRE) Ph.D. grant from Bretagne Plants Innovation, acting on behalf of ACVNPT (Association des Createurs de Variétés Nouvelles de Pomme de Terre).

(c) 2019 The American Phytopathological Society
(Kirk et al. 2005; Nega 2014). In this context, the enhancement of plant immunity (induced resistance) could be a promising strategy for more sustainable protection of potato crops (Walters et al. 2007).

$P$. infestans is able to infect all vegetative organs of the potato plant (Fry 2008). Its trophic status is a much-debated issue. Many authors consider $P$. infestans as a hemibiotrophic pathogen, in which an initial biotrophic phase enables the establishment of the pathogen within its host. It is followed by a necrotrophic stage characterized by expanding necrotic lesions (Fry 2008). During the biotrophic stage, the pathogen develops haustoria to absorb cellular nutrients from living cells (Yi and Valent 2013) and, then, generates asexual sporangia responsible for disease transmission. This observation, together with reports on the kinetics of host defense responses after infection, cast doubt as to the actual status of necrosis for pathogen development and fitness. This led Kröner et al. (2011) to propose a synthetic infection model that regards $P$. infestans essentially as a biotrophic pathogen. In this model, the production of necrosis (i.e., the visible symptoms of the disease) is essentially a side effect of the balance between pathogen growth and plant defense induction in response to infection. The pathogen colonizes and feeds from as-yet healthy plant tissue, triggering, in turn, the accumulation of antimicrobial defense metabolites (i.e., chlorogenic acid, phenolamides, and flavonols, including rutin and nicotiflorin [Kröner et al. 2012]) in tissues that then become necrotic. If this model were correct, the pathogen would actually use growth to escape induced plant defenses.

As a consequence, and since $P$. infestans strains differ in their colonization strategies in nature (Clément et al. 2010), slowgrowing strains would be more affected than fast-growing ones by the plant defenses they induce. Another expected consequence of the Kröner et al. (2011) model is that defense induction ahead of pathogen colonization should reduce the dynamics of disease expansion. Such a prepositioned defense induction could result either from constitutive expression of key genes involved in defense pathways-indeed, this is the case in some potato cultivars with high quantitative resistance to late blight (Saubeau et al. 2016) —or from timely application of defense elicitors such as pathogen-associated molecular patterns (PAMPs) or other exogenous molecules. For instance, in greenhouse experiments, induced resistance by $\beta$-aminobutyric acid (BABA) protects potato from late blight infection for up to five days. Under field conditions, this elicitor could save 20 to $25 \%$ of the fungicide dose, with the same result on late blight development as a full dose of fungicide (Liljeroth et al. 2010). We showed that a concentrated culture filtrate (CCF) of 
P. infestans, containing four active compounds, i.e., three elicitins (INF1, INF4, and INF5) and one polysaccharide (Saubeau et al. 2014), acts as a PAMP (Desender et al. 2006). Moreover, it induces the phenylpropanoid pathway in potato tubers and a number of hormone pathways on potato leaflets (Kröner et al. 2011; Saubeau et al. 2016). Interestingly, its action is genotype-dependent (Saubeau et al. 2016) but its effect on strains with different growth rates has yet to be evaluated.

The objective of this paper, which connects mechanistic analysis with ecological observations, was therefore to validate the Kröner et al. (2011) model by testing some of its key assumptions and predictions. In particular, we wanted to determine whether the effectiveness of induced defense responses in potato depends on pathogen growth rate. Therefore, we monitored simultaneously the induction of defense mechanisms by $\mathrm{CCF}$ and $P$. infestans life history traits from 3 to 5 days postinoculation (dpi). The study was carried out under controlled conditions, using a susceptible potato cultivar without known major resistance genes. Defense-gene expression was assessed by targeting specific potato genes involved in different metabolic pathways. Pathogen development was characterized by measuring necrosis area, quantifying $P$. infestans mycelium DNA in planta (after removing the sporangia from the samples), and counting sporangia.

\section{RESULTS}

Potato plants were sprayed with either CCF or water and were inoculated $48 \mathrm{~h}$ later with four strains of $P$. infestans differing in lesion growth rate (two fast-growing and two slowgrowing) (Table 1) or with water (mock inoculated).

Normalized transcripts accumulation $(\Delta \mathrm{Cq})$ of defense genes involved in selected metabolic pathways was presented as histograms. All data shown are the means and standard errors of the mean from two independent experiments.

\section{After pretreatment with CCF, there are no longer any differences between slow- and fast-growing strains.}

Without pretreatment, necrosis area was significantly higher at 3 and 4 dpi with fast-growing strains than with slow-growing ones $\left(P\right.$ values $1.77 .10^{-4}$ and $\left.9.82 .10^{-7}\right)$ (Fig. 1A). The amount of mycelium DNA was significantly higher at 3 and 4 dpi with fast-growing than with slow-growing strains, but the opposite was true at $5 \mathrm{dpi}(P$ values $0.01,0.05$, and 0.03$)$ (Fig. 1B). Sporangia production was significantly higher at 4 dpi in fastgrowing than in slow-growing strains ( $P$ value 0.002$)$ (Fig. 1C).

However, CCF treatment two days before inoculation resulted in a complete absence of significant differences between fast-growing strains and slow-growing ones for the three life history traits studied (except for necrosis area at $5 \mathrm{dpi}$, which was larger with fast-growing strains). Necrosis area relative to that in the water control decreased significantly after pretreatment for the fast-growing strains at 3 and 4 dpi ( $P$ values $4.83 .10^{-4}$ and $4.77 .10^{-5}$, respectively), making them equivalent to that in slow-growing strains with or without pretreatment (Fig. 1D). Pathogen mycelium DNA increased significantly after treatment with $\mathrm{CCF}$ at 4 and $5 \mathrm{dpi}$ for the fast-growing strains ( $P$ values $3.15 .10^{-4}$ and $\left.4.15 .10^{-3}\right)$ but only at 4 dpi for the slow-growing ones $(P$ value 0.024$)$ (Fig. 1B). Sporangia production decreased significantly after treatment with $\mathrm{CCF}$ at 4 and $5 \mathrm{dpi}$ for the fast-growing strains $(P$ values 0.028 and $0.032)$ and only at $5 \mathrm{dpi}$ for the slow-growing strains $(P$ value 0.046) (Fig. 1C).

\section{Both $P$. infestans and its CCF induce defense responses on cv. BF 15.}

Defense transcripts accumulated $48 \mathrm{~h}$ after spraying CCF, just before mock inoculation ( $0 \mathrm{dpi})$, compared with watertreated controls (Fig. 2). This effect persisted at 3 and 4 dpi for $P R-2, P R-3, P R-4, P O T L X 3$, and EIN3, while $P R-1$ and THT tended to increase only at $3 \mathrm{dpi}$. CCF treatment did not alter $P A L$ and $P O X$ accumulation.

A similar experiment was carried out using $P$. infestans rather than its culture filtrate. For both strains, the accumulated level of defense transcripts was higher at 3 and 4 dpi in inoculated leaflets than in noninoculated controls (Fig. 3). These differences were significant at 3 dpi for $P R-1$ ( $P$ value 0.1$), E I N 3$ ( $P$ value 0.15$)$, and at 4 dpi for $P R-2(P$ value 0.01$)$. At $3 \mathrm{dpi}$, only fast-growing strains induced a significant increase of $P R-2, P R-4, T H T, P O X, P O T L X 3$ ( $P$ value 0.03$), P R-3$ ( $P$ value $0.08)$, and $P A L$ ( $P$ value 0.16$)$. This effect remained significant at 4 dpi for POTLX3 $(P$ value 0.03$)$ and to a lesser extent for $P O X$ and $T H T$ ( $P$ value 0.16$)$.

\section{$P$. infestans increases defense-gene expression induced by CCF.}

The combination of both $\mathrm{CCF}$ and $P$. infestans effects were compared with mock-inoculated leaflets (Fig. 4). Fast-growing strains increased $P R-1$ expression at $4 \mathrm{dpi}(P$ value 0.02$)$ and $T H T$ expression from 3 to 4 dpi $(P$ value 0.08$)$. However, slowgrowing strains increased $P R-1$ expression at 3 dpi $(P$ value $0.04)$ and $T H T$ expression only at $4 \mathrm{dpi}(P$ value 0.08$)$. After inoculation, there was no significant change on $P R-2, P R-3$, PR-4, POTLX3, and EIN3 expression.

The induction of $P R-1, P R-4, P A L, T H T$, and $P O X$ is strain-dependent after pretreatment with CCF.

After pretreatment with $\mathrm{CCF}$ and at $4 \mathrm{dpi}$, gene induction was strain-dependent (Fig. 5). $P R-1$ and $P O X$ were, thus, more accumulated at 4 dpi with fast-growing strains than with slowgrowing ones ( $P$ values 0.04 and 0.02 ). With fast-growing strains, we also observed a greater accumulation of $P R-4, P A L$, and $T H T$ at 4 dpi, less significant, however, than $P R-1$ and $P O X$ ( $P$ value $0.15,0.08$, and 0.15 , respectively). For the four remaining genes, no changes were observed for either strains.

\section{DISCUSSION}

\section{Pathogen life history traits are impacted} by host elicitation before inoculation.

This study aimed to determine whether the effectiveness of induced defense responses in potato depends on pathogen life history traits related to aggressiveness, in particular, lesion

Table 1. Detailed informations about the four Phytophthora infestans strains

\begin{tabular}{|c|c|c|c|c|c|}
\hline Strain name & Strain type (growth rate) & Clonal lineage & Year & Origin & Organ \\
\hline 10.P15.06 & Fast growing $(\mathrm{S}+)$ & 13_A2 & 2010 & Field: Ploudaniel (29, France) & Leaflets, cv. Bintje \\
\hline 14.P29.03 & Slow growing $(\mathrm{S}-)$ & 13_A2 & 2014 & Field: Trévou-Tréguignec (22, France) & Leaflets, cv. Amandine \\
\hline 14.P29.03.R & Fast growing $(\mathrm{S}+)$ & 13_A2 & 2016 & $\begin{array}{l}\text { Experimental evolution trial: INRA Le Rheu } \\
(35, \text { France })\end{array}$ & Tubers, cv. Bintje \\
\hline 10.P15.06.R & Slow growing $(\mathrm{S}-)$ & 13_A2 & 2016 & $\begin{array}{l}\text { Experimental evolution trial: INRA Le Rheu } \\
(35, \text { France })\end{array}$ & Tubers, cv. Bintje \\
\hline
\end{tabular}


growth rate. Our results indeed showed that, after pretreatment with $\mathrm{CCF}$, fast-growing strains behave like slow-growing ones, suggesting that $\mathrm{CCF}$ affects the ability of strains to actively colonize host tissue and to reproduce. These results are consistent with earlier observations in potato plants pretreated with a sugar beet extract or with BABA, a synthetic defense elicitor. Both of which showed a significant reduction in lesion size and lower sporangial production (Bengtsson et al. 2014; Moushib et al. 2013). In other pathosystems, pretreatment of grapevine leaves with benzothiadiazole led to a strong inhibition of fungal
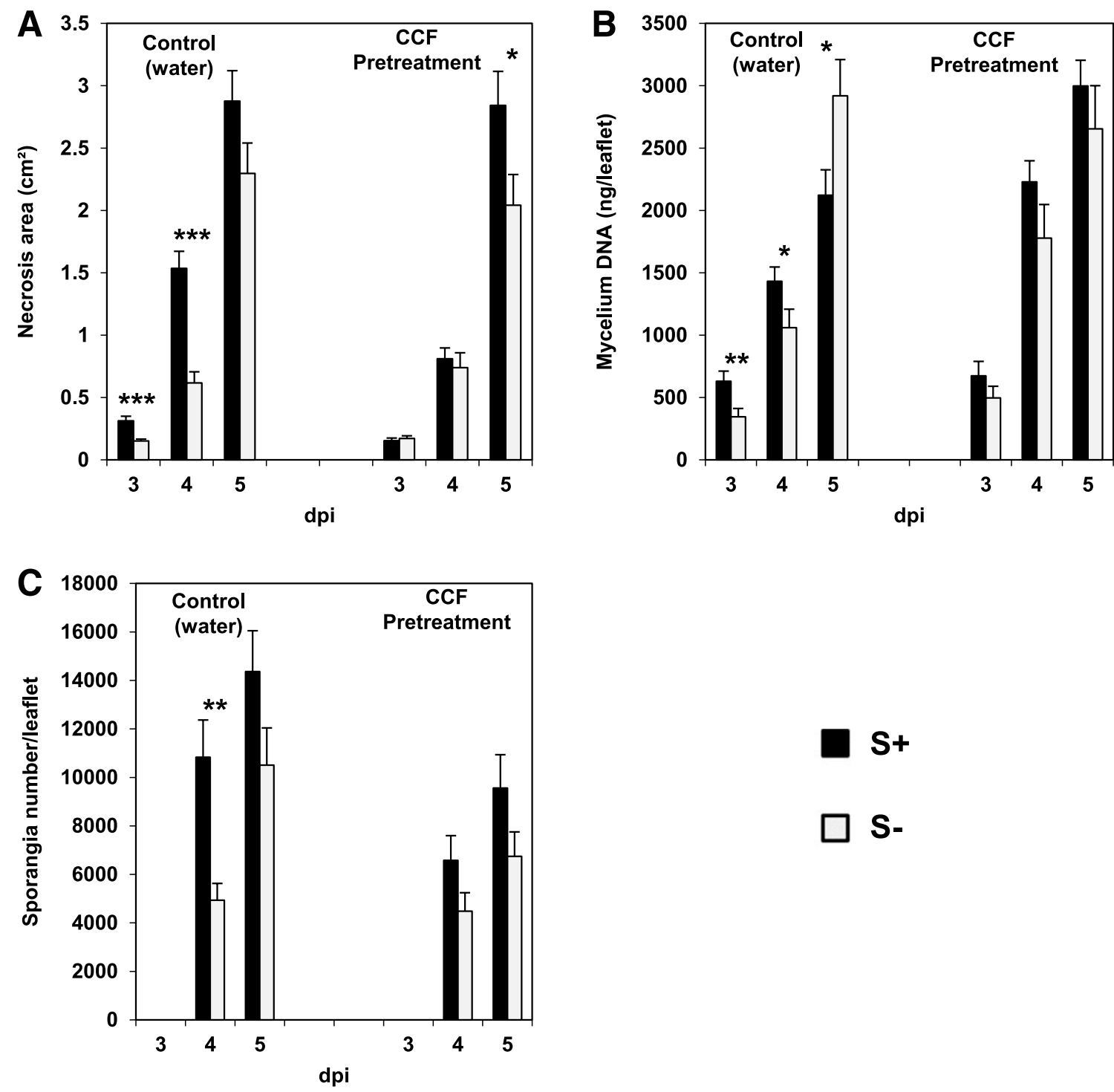

S+

\section{S-}

D

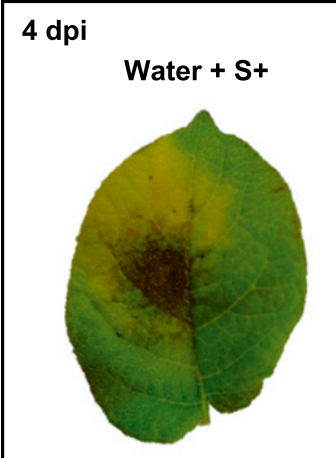

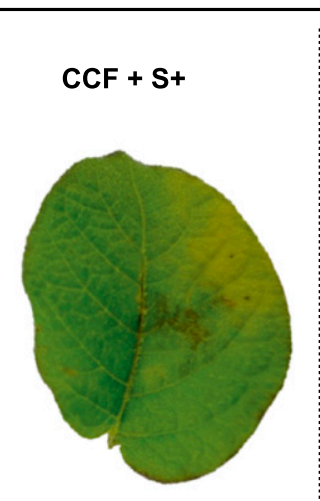

$4 \mathrm{dpi}$

Water + S-

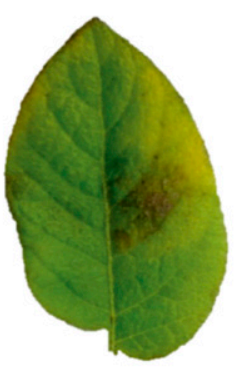

$\mathrm{CCF}+\mathrm{S}-$

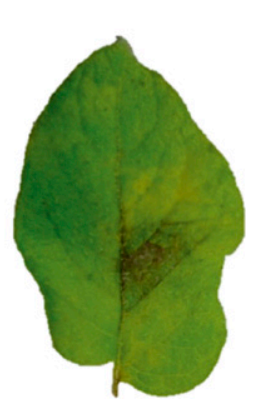

Fig. 1. Strain effect on Phytophthora infestans life history traits. A through D, Necrosis area (A and D), mycelium DNA (B), and sporangia number (C) on cv. BF 15 potato leaflets sprayed with either concentrated culture filtrate $(\mathrm{CCF})$ or water (control), from 3 to 5 days postinoculation (dpi) with $P$. infestans $(\mathrm{S}+=$ fast-growing strains or $\mathrm{S}-=$ slow-growing strains). Data represent the mean + standard error of the mean, $n=24$; results were repeated in two independent experiments. The strain effect was tested for each day, with or without CCF pretreatment (analysis of variance: one asterisk (*) indicates $P$ value $<0.05$, two (**) $P$ value $<0.01$, three $(* * *) P$ value $<0.001)$. 
mycelium growth and sporulation of the biotrophic pathogens Plasmopara viticola and Erysiphe necator (Dufour et al. 2013).

It should be noted that changes in symptom growth rate are not always consistent with those in pathogen biomass, as measured by fungal DNA accumulation. Indeed, we observed that the reduction in symptom extension after $\mathrm{CCF}$ treatment was associated with an accumulation of pathogen DNA. Our results agreed with those of Paulert et al. (2009), who demonstrated that ulvans decreased anthracnose symptoms but increased mycelium growth and conidia germination of Colletotrichum lindemuthianum in vitro. On the contrary, Bengtsson et al. (2014) and Floryszak-Wieczorek
PR1

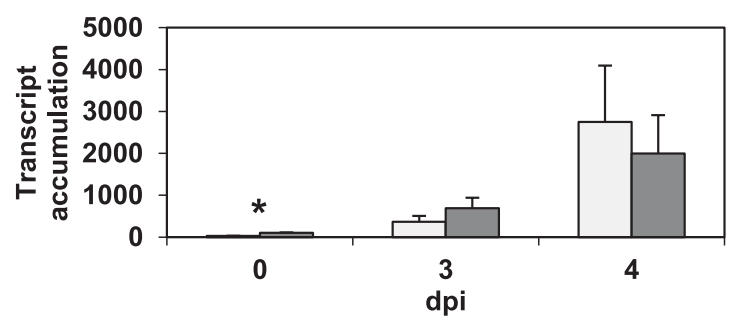

PR3

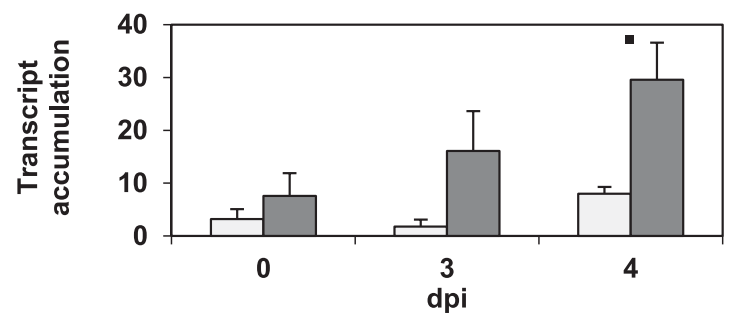

PAL

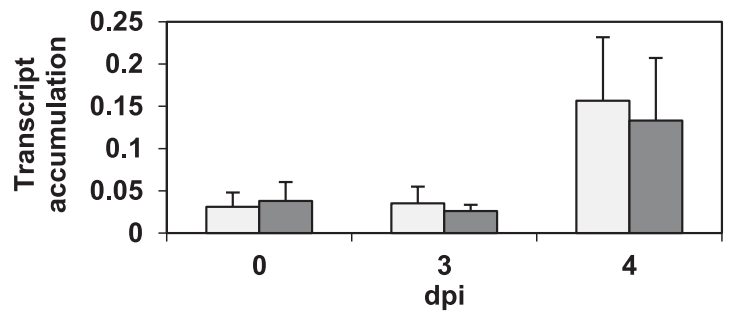

POX

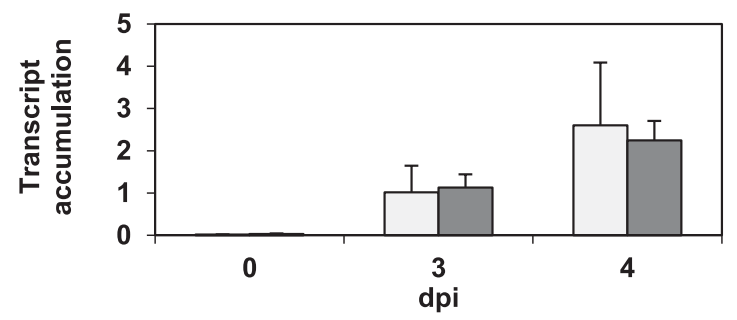

EIN3

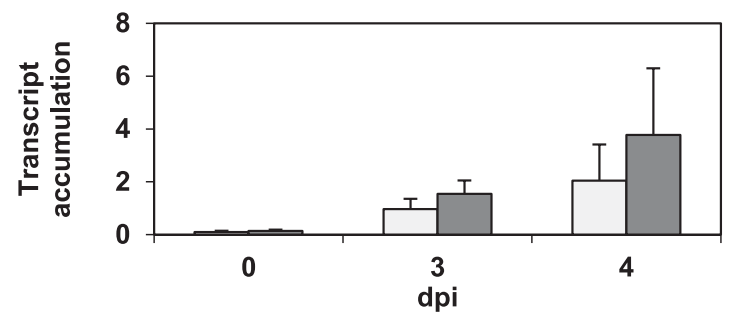

PR2

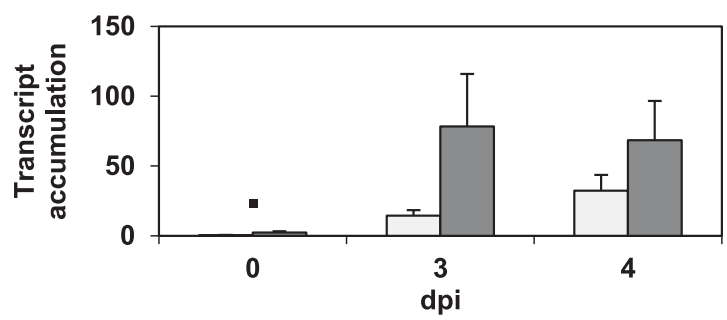

PR4

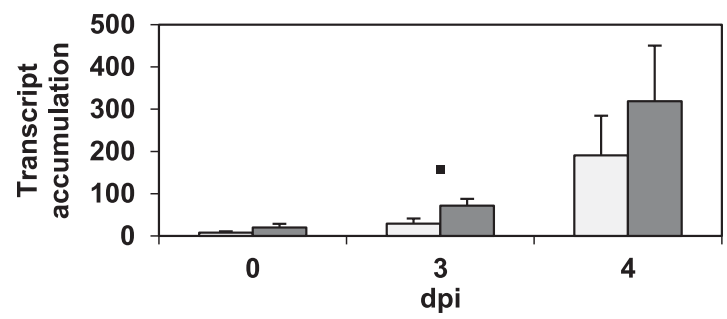

THT

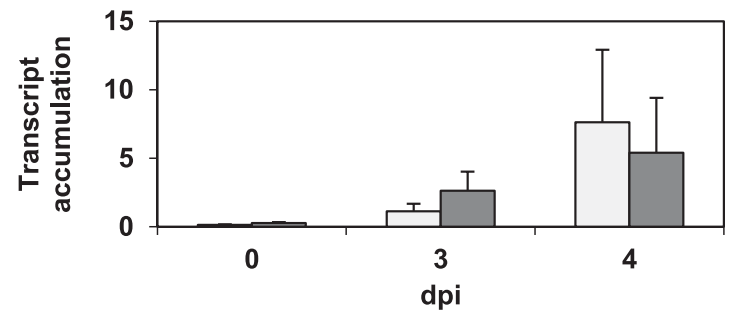

POTLX3

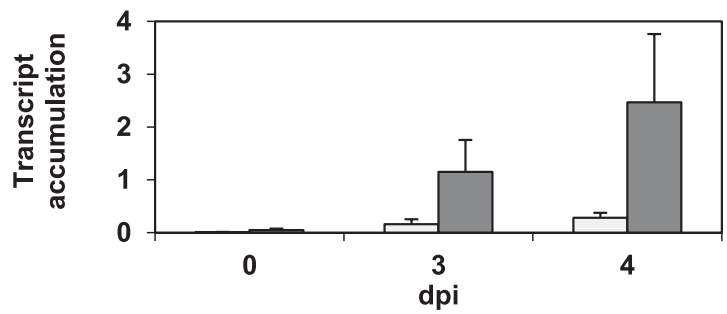

Control (water)

CCF Pretreatment

Fig. 2. Concentrated culture filtrate $(\mathrm{CCF})$ pretreatment effect on defense-gene expression. Transcript accumulation of defense genes involved in various signaling pathways in potato cv. BF 15, sprayed with either CCF or water (control), from 0 to 4 days post-mock inoculation (dpi). Data represent the mean + standard error of the mean, $n=4$; results were repeated in two independent experiments. The CCF pretreatment effect was tested for each day (Kruskal Wallis: a black square symbol $(\square)$ indicates $P$ value $<0.1$, an asterisk $(*) P$ value $<0.05)$. 
et al. (2015) reported a simultaneous reduction in both traits in potato plants pretreated with BABA.

Our data showed that the reduction in lesion growth rate following CCF pretreatment only acts on fast-growing strains. It is interesting to note that the reduction in lesion growth rate caused by pretreatment is independent of a direct toxic activity of the elicitor. Indeed, the sugar beet extract used by Moushib et al. (2013) has no direct toxicity on the pathogen, whereas $\mathrm{CCF}$ has a limited but significant impact on mycelium growth in vitro (Kröner et al. 2012), pointing to the likely involvement

PR1

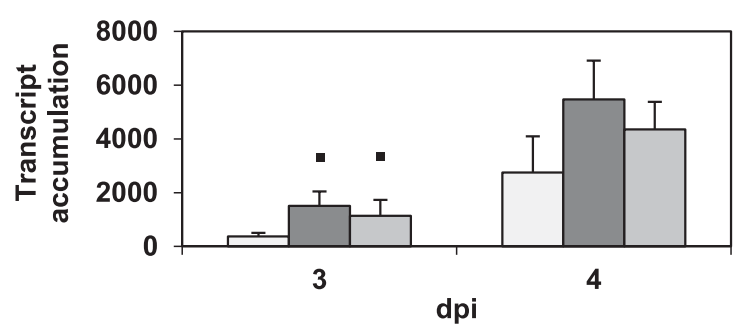

PR3

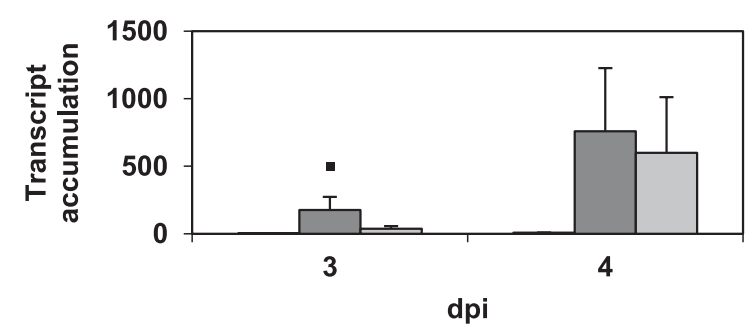

PAL

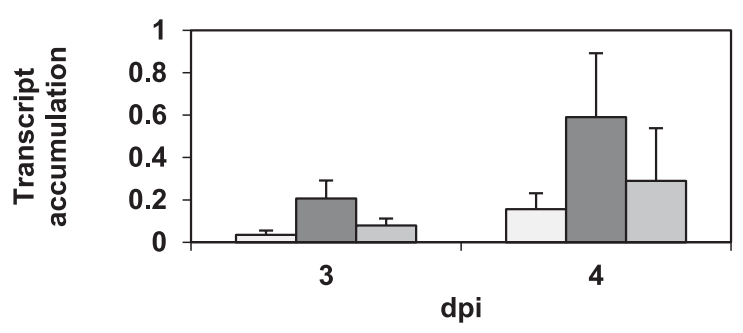

POX

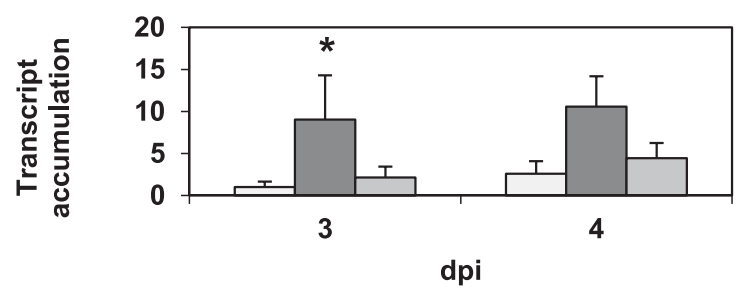

EIN3
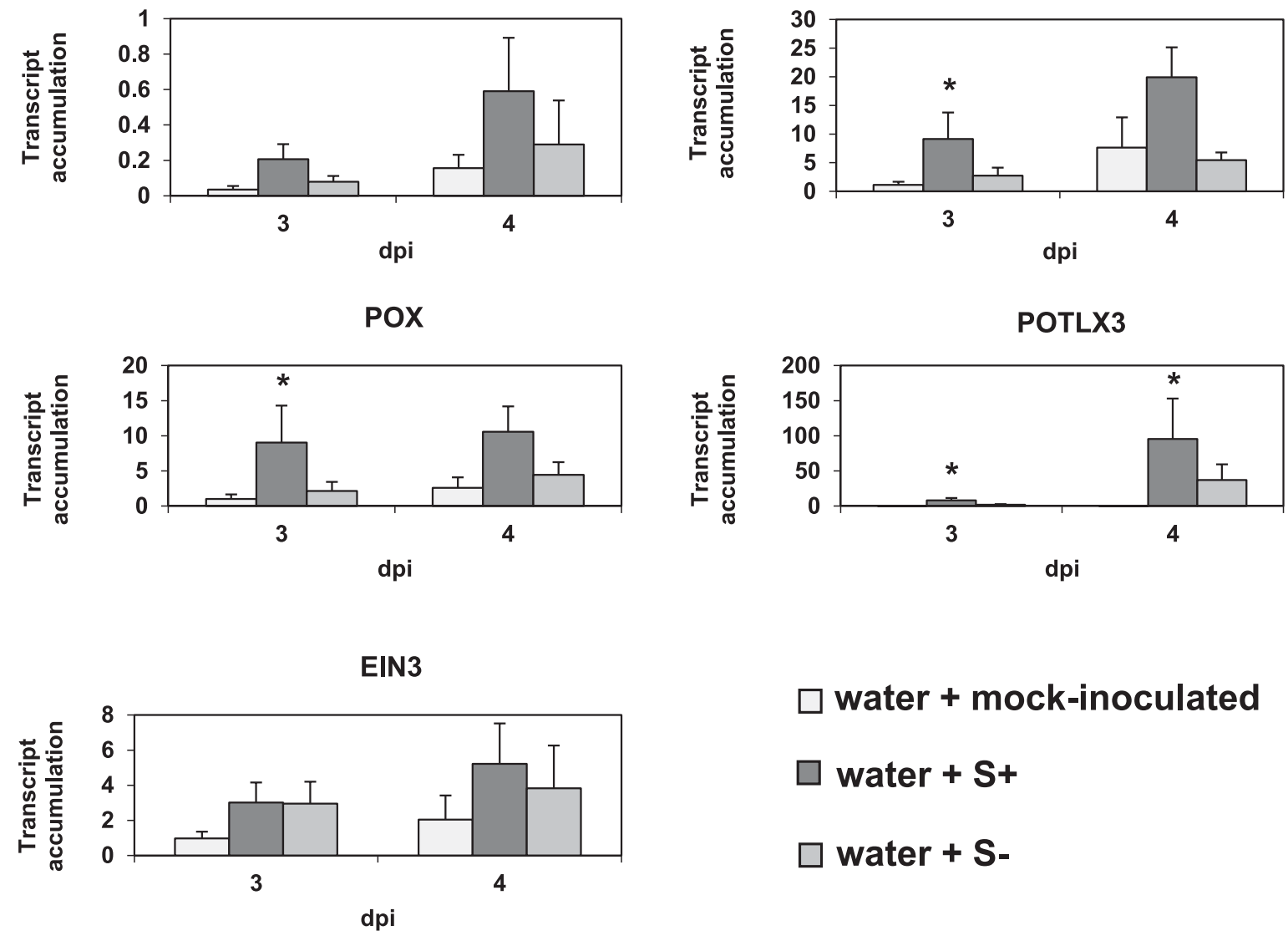

POTLX3

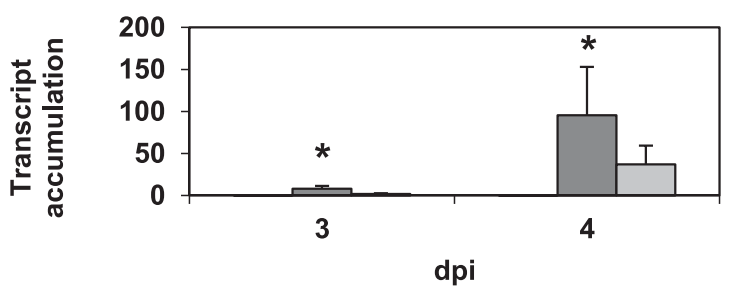

water + mock-inoculated

water + S+

water + S-

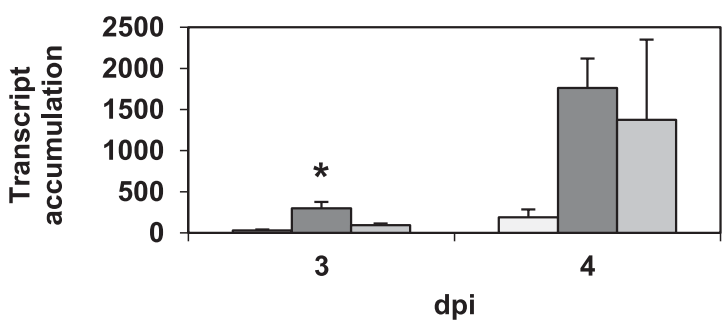

THT 
of defense induction as the cause for the reduction of symptom extension in pretreated tissue. CCF has been proved to induce various defense metabolic pathways on cv. BF 15 (Saubeau et al. 2016). Furthermore, our results showed that some defense genes, such as those coding PR proteins, were induced by all
$P$. infestans strains. The consistently stronger induction by the pathogen itself compared with a single CCF application could be due either to a lower PAMP concentration in CCF, to the lasting secretion of PAMPs in the plant-P. infestans interaction, or to both. This latter hypothesis is supported by the fact that
PR1

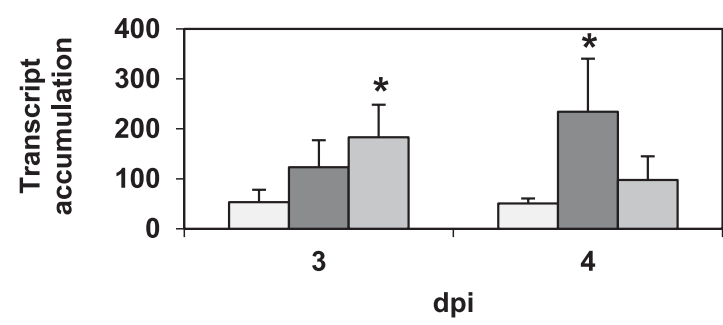

PR3

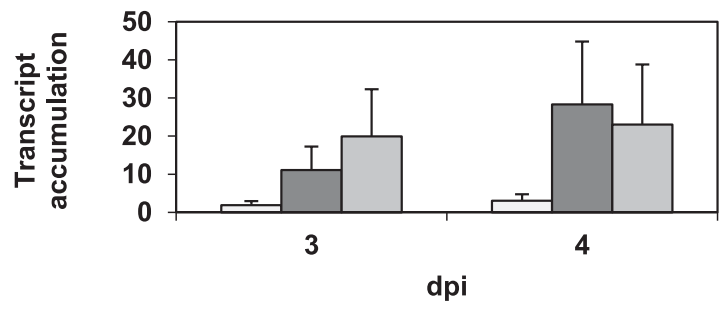

PAL
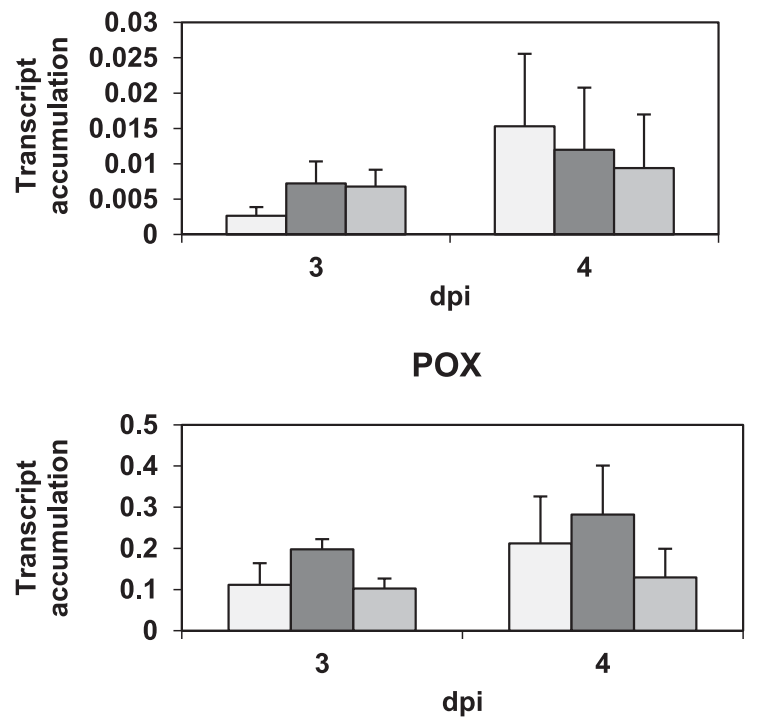

EIN3

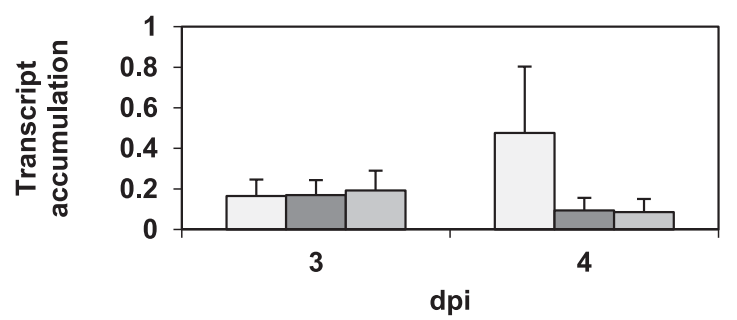

PR2

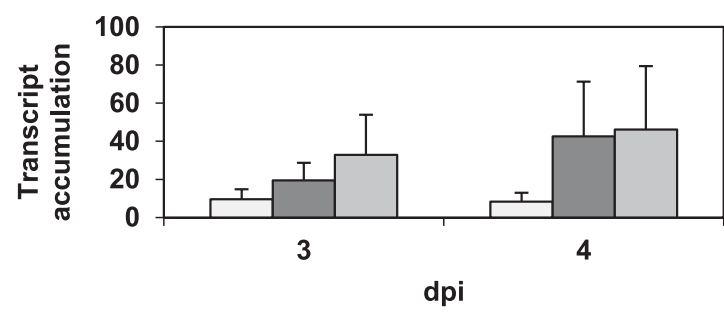

PR4

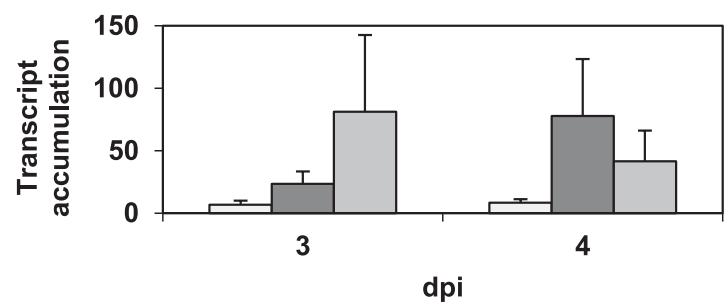

THT

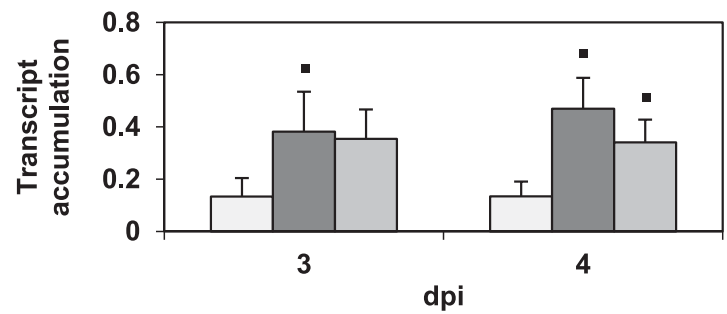

POTLX3

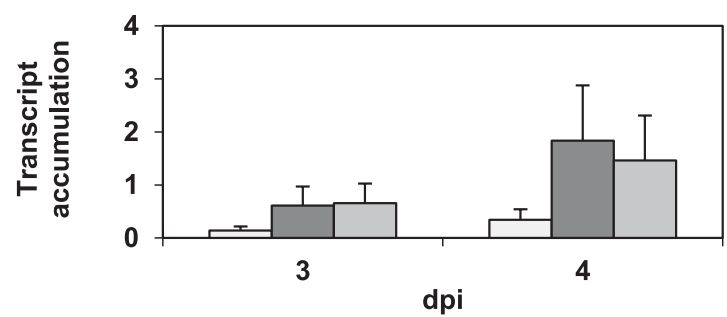

CCF + mock-inoculated $\mathrm{CCF}+\mathrm{S}+$

Fig. 4. The effect on defense-gene expression of a combination of concentrated culture filtrate (CCF) and $P$. infestans. Transcript accumulation of defense genes involved in various signaling pathways in potato cv. BF 15 sprayed with $\mathrm{CCF}$, from 3 to 4 days postinoculation (dpi) with $P$. infestans $(\mathrm{S}+=$ fast-growing strains, $\mathrm{S}-=$ slow-growing strains) or mock-inoculated (control). Data represent the mean + standard error of the mean, $n=4$; results were repeated in two independent experiments. The combination of both CCF and $P$. infestans was tested for each day and for each strain, compared with mock-inoculated leaflets (Kruskal Wallis: a black square symbol ( $\square$ ) indicates $P$ value $<0.1$, one asterisk $(*) P$ value $<0.05$ ). 
the fast-growing strains of $P$. infestans caused a higher defense induction than their slow-growing counterparts.

\section{Do different life history strategies in pathogen strains} explain differences in induced resistance?

We observed that the patterns and timing of defense-gene expression varied extensively, depending on the type of strain (fast- or slow-growing). There was a higher accumulation of $P O X$ and THT transcripts at 3 and 4 dpi, respectively, with fastrather than with slow-growing strains, as were $P R-1, P R-4$, and $P A L$ at $4 \mathrm{dpi}$ in leaflets pretreated with $\mathrm{CCF}$ (Fig. 5). This suggests that fast- and slow-growing strains may have different strategies relative to resistance induction. As suggested by Kröner et al. (2011), fast-growing strains might attempt to

PR1

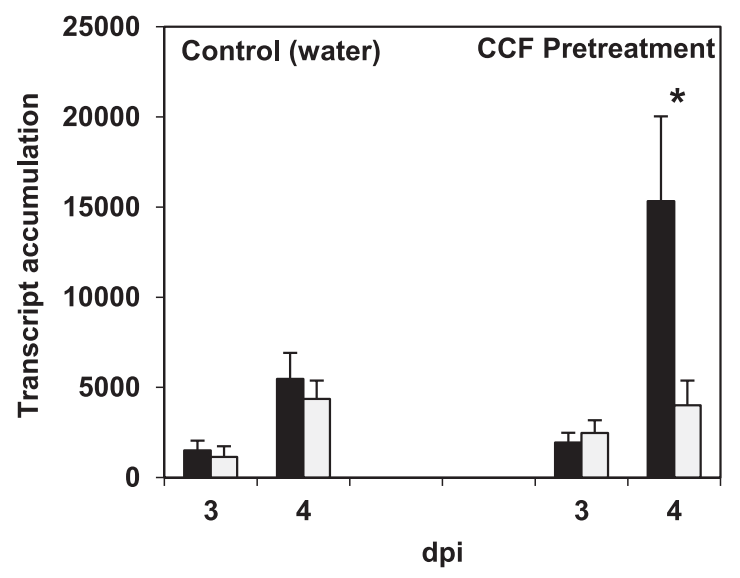

PAL
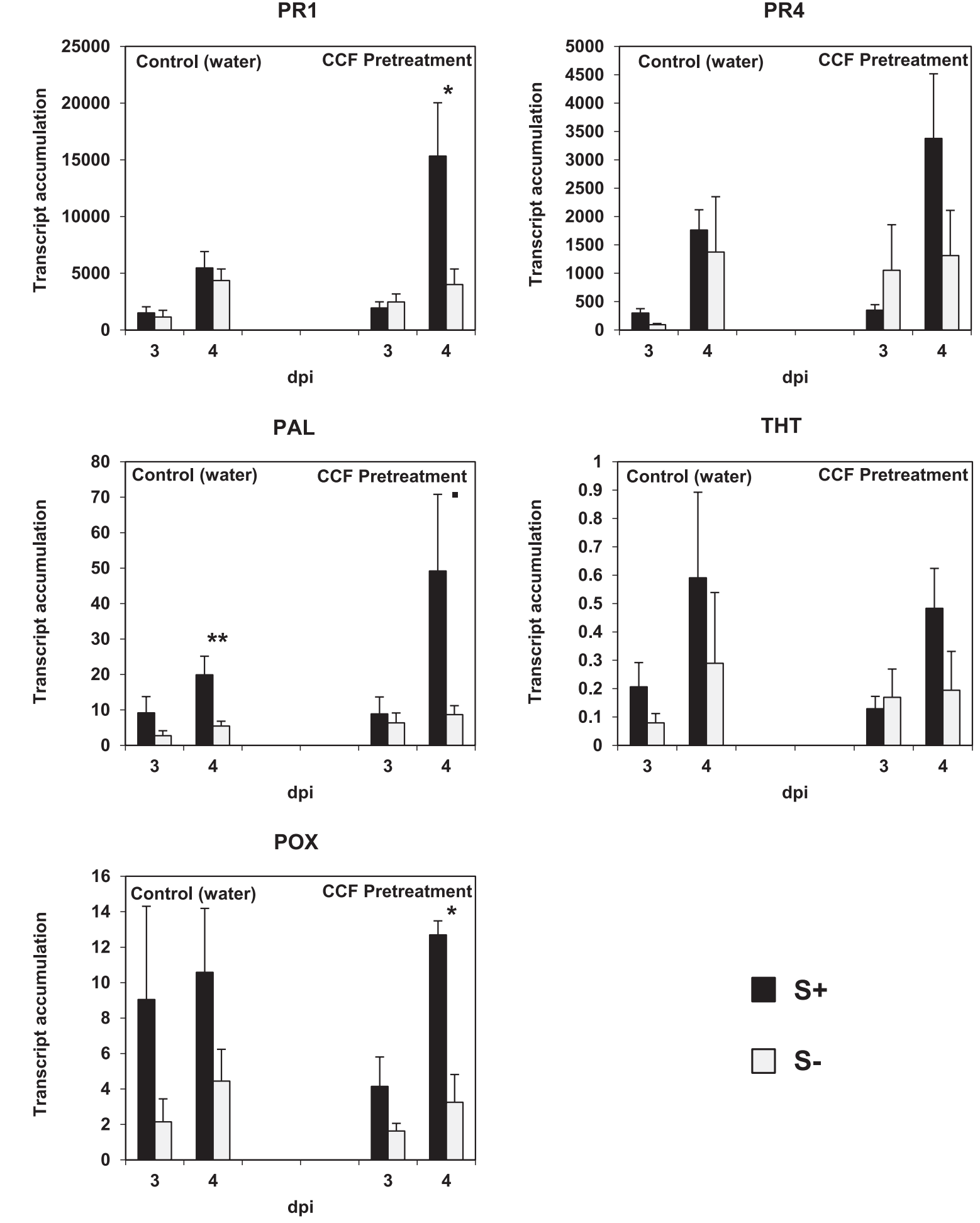

THT

Fig. 5. Strain effect on defense-gene expression. Transcript accumulation of defense genes involved in various signaling pathways in potato cv. BF 15 , sprayed with either concentrated culture filtrate (CCF) or water (control), from 3 to 4 days postinoculation (dpi) with Phytophthora infestans $(\mathrm{S}+=$ fast-growing strains, $\mathrm{S}-=$ slow-growing strains). Data represent the mean + standard error of the mean, $n=4$; results were repeated in two independent experiments. The strain effect was tested for each day, with or without CCF pretreatment (Kruskal Wallis: a black square symbol ( $\square$ ) indicates $P$ value $<0.1$, one asterisk (*) $P$ value $<0.05$, two asterisks $(* *) P$ value $<0.01)$. 
escape plant defenses by their growth rate rather than to overcome them. On the contrary, slow-growing strains could face defenses induced by PAMPs and may have to develop counterdefense strategies, such as detoxifying antimicrobial compounds or secreting effectors. Under these hypotheses, it is logical that prepositioned induced resistance would be more efficient against fast-growing strains than slow-growing ones. This differential impact of induced resistance ahead of inoculation on fast-growing ('escape' strategists) and slowgrowing ('adapt' strategists) strains, therefore, explains why $\mathrm{CCF}$ pretreatment eliminates differences between both groups in in-vivo biotests.

\section{Potential consequences for biocontrol and epidemic management of late blight.}

The differential effect of induced defense responses on fastand slow-growing strains raises further questions about the ecology of interactions, as well as opportunities to exploit these in biocontrol strategies of late blight epidemics.

Since $P$. infestans populations are often structured as clonal lineages (Clément et al. 2010), it would be important to determine to what extent genotypic variation is related to pathogen strategies. The fact that all strains used in the present work belong to a single clonal lineage (13_A2) strongly suggests that life history strategies are largely independent of clonal lineages. Identifying either specific molecular markers or fast biotests to analyze the proportion of fast- and slow-growing strains within a given pathogen population should allow us to better predict the field performance of defense-inducing elicitors.

The other important dimension that remains to be explored is the consistency of the patterns described here over a range of host cultivars, notably those with different levels of quantitative resistance. Earlier works have, indeed, shown that quantitative resistance acts by affecting pathogenicity-related life history traits (Clément 2011) in a strain- and cultivardependent manner similar to the one reported here with induced resistance. Therefore, one can expect that the performance of resistance induction in the control of late blight progress will differ according to the mechanisms active in host cultivars. Together with the natural variability in life history strategies within populations, this cultivar dependence may explain a large fraction of the inconsistent performance of defense elicitors under field conditions.

This study, therefore, represents a first attempt to relate ecological characteristics of pathogen strains and mechanistic determinants of host-pathogen interactions, in a perspective to better exploit and improve the performance of biocontrol.

\section{MATERIALS AND METHODS}

\section{Inoculum and elicitor preparation.}

Four P. infestans strains-10.P15.06, 10.P15.06.R, 14.P29.03, 14.P29.03.R—belonging to the 13_A2 clonal lineage (Table 1) were used as pairs of strains differing by their growth speed in the experiments. The first experiment involved strains 10 . P15.06 (fast-growing) and 14.P29.03 (slow-growing), while the second experiment used strains 14.P29.03.R (fast-growing) and 10.P15.06.R (slow-growing).

$P$. infestans transplants were cultivated in petri dishes filled with pea agar. After 3 weeks on axenic cultures, $P$. infestans sporangia were collected with sterile distilled water. To increase its pathogenicity, detached leaflets of cv. Bintje (susceptible to $P$. infestans) were inoculated with each strain separately. Eight days later, after incubation in a humid chamber under controlled conditions $\left(18^{\circ} \mathrm{C}\right.$-day and $15^{\circ} \mathrm{C}$-night temperatures, with $16 \mathrm{~h}$ of daylight), sporangia were collected from the leaflets in sterile water. Sporangial suspensions were adjusted to a final concentration of $5 \times 10^{4}$ sporangia $\mathrm{ml}^{-1}$, using a hemocytometer. Suspensions were kept at $4^{\circ} \mathrm{C}$ for $2 \mathrm{~h}$ to promote zoospore release (Mariette et al. 2016; Montarry et al. 2007).

P. infestans CCF was prepared from strain 10.P15.06 mycelium grown, for 3 weeks, as agitated axenic cultures in pea broth (Desender et al. 2006). Mycelium was then eliminated by filtration on sterile gauze (40 mesh; Laboratoires Euromedis France) and the filtrate was lyophilized for $72 \mathrm{~h}$. The lyophilisate was diluted in water at $8 \mathrm{mg} \mathrm{ml}^{-1}$ and $0.1 \%$ Tween 20 (Saubeau et al. 2016).

\section{Cultivation and treatment of plants.}

Tubers of Solanum tuberosum (L.) cultivar BF 15 were grown in pots (one tuber per pot) filled with Falienor, Terreau de France NFU44-55 in a greenhouse at $20 \pm 3^{\circ} \mathrm{C}$ with a $16-\mathrm{h}$ photoperiod. Two independent experiments were carried out 9 and 4 weeks after planting. During the second experiment, plants were watered once a week with a nutrient solution (NPK 15/10/15; Hakaphos). Then, plants were sprayed to runoff with either $\mathrm{CCF}$ at $8 \mathrm{mg} \mathrm{ml}^{-1}(+0.1 \%$ Tween 20$)$ or sterile water (+0.1\% Tween 20, control).

\section{Experimental design.}

Two independent experiments were conducted, each with a different pair of strains. Each experiment tested 12 treatments, i.e., all possible combinations of two strain types (fast- or slowgrowing; respectively called $\mathrm{S}+$ and $\mathrm{S}-$ ), two leaflet pretreatments before inoculation (water or CCF), and three observation dates $(3,4$, or 5 dpi). Each treatment involved 12 leaflets.

\section{Sampling of leaflets and inoculation.}

Leaflets used for each experiment were picked at random from the third and fourth leaf levels below the apex, $48 \mathrm{~h}$ after pretreatment. Twelve leaflets from each pretreatment were frozen, immediately after sampling, in liquid nitrogen to assess plant defenses. The remaining leaflets were inoculated on the abaxial surface with a $20-\mu \mathrm{l}$ droplet of $P$. infestans sporangial suspensions or sterile water (mock inoculated). After inoculation, leaflets were placed on the lids of petri dishes containing $2 \%$ water agar to promote high humidity.

\section{Assessment of potato defense genes by quantitative reverse transcription-polymerase chain reaction (qRT-PCR).}

In each experiment, the expression of nine defense genes was assessed $48 \mathrm{~h}$ after pretreatment (i.e., just before inoculation) and at 3 and $4 \mathrm{dpi}$. The 12 leaflets from each treatment were pooled, were frozen in liquid nitrogen, and were ground to a fine powder. This powder was distributed as 100-mg aliquots into 2-ml cryogenic tubes.

RNA was then extracted independently from two of these aliquots, as described by Saubeau et al. (2016). The integrity of the RNA was determined either by the RNA integrity number ( $\mathrm{RIN} \geq 6.5$ ), for the first experiment, or by electrophoresis on $1 \%$ agarose gel, for the second experiment.

Each RNA sample was then amplified in three qRT-PCR reactions. Defense-gene expression was assessed with a tool targeting specific potato genes involved in various metabolic pathways (Saubeau 2014). The expression of nine potato defense genes (Table 2) (all provided by Sigma-Aldrich Chimie S. a.r.l France) was analyzed at 3 and 4 dpi with qRT-PCR in leaf samples sprayed or not with CCF and inoculated or not with $P$. infestans. qRT-PCR was performed and analyzed according to Saubeau et al. (2016), with several modifications; the SYBR Premix Ex Taq (Takara, provided by Ozyme) was replaced by the LightCycler 480 SYBR Green I Master (Roche Diagnostics 
France), and three reference genes (Actin 7, ribosomal protein $L 2$, and $G A P D H$ ) were used to calculate the normalization factor. Primers (desalt purification) were distributed into 384-well reaction plates with a Hamilton MICROLAB STAR 8 300- $\mu$ l automation system (Hamilton France S.a.r.l), while the LightCycler SYBR Green Master I, cDNAs, and water were pipetted manually.

The $\mathrm{Cq}$ average was calculated for each condition from duplicates of two independent experiments (RNA from two aliquots per experiment, each pipetted into three qRT-PCRs). Then, effects of CCF and $P$. infestans on potato defense responses were tested at each point of the kinetic.

To study the effects of CCF, $P$. infestans, and the combination of both $\mathrm{CCF}$ and $P$. infestans effects on transcripts accumulation, $\mathrm{Cq}$ were normalized with reference genes and $\Delta \mathrm{Cq}$ were represented on histograms.

\section{Tracking pathogen development: necrotic lesion,} mycelium quantification, sporangia number.

Pathogen development was evaluated at 3, 4, and 5 dpi by measuring necrosis area, quantifying mycelium DNA in planta, and counting sporangia on infected leaflets pretreated or not with $\mathrm{CCF}$.

\section{Necrotic lesion.}

Necrotic lesions were measured with a caliper on the upper surface of the leaflets and were calculated with the formula used by Vleeshouwers et al. (2000), assuming an elliptic shape:

$$
\text { Necrotic area }=\text { length } \times \text { width } \times \pi \times 1 / 4 \text {. }
$$

\section{Sporangia number.}

Sporangia were collected in $10 \mathrm{ml}$ of sterile water and were centrifuged $3 \mathrm{~min}$ at $3,000 \times g$. Then, the pellets were diluted in $4 \mathrm{ml}$ of Isoton II (saline buffer) (Beckman Coulter) and were frozen $\left(-20^{\circ} \mathrm{C}\right)$ in hemolytic glass tubes. Sporangia were counted with a Z2 Coulter Counter analyzer (Beckman Coulter), calibrated between 10 and $21 \mu \mathrm{m}$ (experiment 1) or with an OCCHIO Flowcell FC200S (Occhio) aperture set on $300 \mu \mathrm{m}$ (experiment 2). Counting was performed with the following settings for the second experiment: $0.2 \mathrm{ml}$ of priming, $0.5 \mathrm{ml}$ of volume analysis, and $10 \%$ of volume sampling. Two filter parameters were used to detect the sporangia, circularity between 0.6 and 1 and area diameter between 13 and $45 \mu \mathrm{m}$.

\section{Mycelium DNA quantification.}

After collecting sporangia, leaflets were put in 2-ml cryogenic tubes containing five glass beads preweighed, lyophilized $24 \mathrm{~h}$, weighed, and ground. Then, DNA was extracted from $5 \mathrm{mg}$ of powder, using the Nucleospin Plant II kit (Machery Nagel) modified. Cell lysis was performed with $600 \mu \mathrm{l}$ of Buffer PL1, $10 \mu \mathrm{l}$ of RNAse A, and $10 \mu \mathrm{l}$ of proteinase K. Samples were incubated $1 \mathrm{~h}$ at $65^{\circ} \mathrm{C}$. Chlorophorm $(100 \mu \mathrm{l})$ was added and samples were centrifugated $15 \mathrm{~min}$ at $20,000 \times g$. After cell lysis, $100 \mu \mathrm{l}$ of supernatant was removed for DNA extraction. Then, DNA was eluted in two steps $(2 \times 100 \mu \mathrm{l}$ of buffer PE) and was conserved at $-20^{\circ} \mathrm{C}$. Total plant and pathogen DNA $(5 \mu \mathrm{l})$ were diluted 1:100 and mycelium DNA from $P$. infestans was quantified by qPCR, according to Lees et al. (2012), after modifications. Amplifications by qPCR were performed in $20 \mu \mathrm{l}$ containing $10 \mu \mathrm{l}$ of LightCycler 480 SYBR Green I Master (Roche), $5 \mu \mathrm{l}$ of DNA (diluted 1:100), $1 \mu \mathrm{l}$ of forward and reverse primer (with a final concentration of $500 \mathrm{nM}$ ), and $3 \mu \mathrm{l}$ of $\mathrm{H}_{2} \mathrm{O}$ PCR-grade. Amplifications were performed using 96-well plates with LightCycler 480 (Roche) under the following cycling conditions: $5 \mathrm{~min}$ at $95^{\circ} \mathrm{C}$; $50 \mathrm{cy}-$ cles of $10 \mathrm{~s}$ at $95^{\circ} \mathrm{C}, 20 \mathrm{~s}$ at $61^{\circ} \mathrm{C}$, and $20 \mathrm{~s}$ at $72^{\circ} \mathrm{C}$, and a dissociation curve analysis from 61 to $95^{\circ} \mathrm{C}$. To calculate concentration of each specific amplicon of $P$. infestans (duplicates), a standard range of a $P$. infestans stock from 10 to $10^{-8}$ $n g \mathrm{l}^{-1}$ (triplicates) was achieved. Analyses were performed with LightCycler 480 software release 1.5.0 (Roche). Then, the amount of $P$. infestans mycelium DNA was expressed as nanograms per leaflet.

\section{Statistical analysis.}

One- and two-way analyses of variance were performed with $\mathrm{R}$ software 3.3.1 function 'aov' for pathogen life history traits.

Table2. Selected genes and corresponding primer sets used for analysis of transcript profiles from Solanum tuberosum leaves (Saubeau 2014)

\begin{tabular}{|c|c|c|c|c|}
\hline Gene name & Gene function & GenBank no. & Primer sequence $\left(5^{\prime}\right.$ to $\left.3^{\prime}\right)$ & Concentration (nM) \\
\hline$P R-1$ & Potato pathogenesis-related protein 1 & AJ250136 & $\begin{array}{l}\text { Forward GGGAGAAGCCAAACTACAACTATG } \\
\text { Reverse ACGAGCCCGACCACAACC }\end{array}$ & 200 \\
\hline$P R-2$ & Potato pathogenesis-related protein 2 ( $\beta$-glucanase) & U01901 & $\begin{array}{l}\text { Forward GATGGAACGAACAGGAGGAG } \\
\text { Reverse GGCTTTCTCGGACTACCTTC }\end{array}$ & 300 \\
\hline$P R-3$ & Potato pathogenesis-related protein 3 (chitinase) & AF024537 & $\begin{array}{l}\text { Forward TGATGTATGTCCTGGCAAAG } \\
\text { Reverse CCACCATTAGTTTCGTGAGATG }\end{array}$ & 300 \\
\hline$P R-4$ & Potato pathogenesis-related protein 4 (hevein-like) & AM908515.1 & $\begin{array}{l}\text { Forward GCGGTAGATGCTTGAGGGTGAC } \\
\text { Reverse GCCCAATCCATTAGTGTCCAATCG }\end{array}$ & 200 \\
\hline$P A L$ & Potato phenylalanine ammonia-lyase 1 & X63103 & $\begin{array}{l}\text { Forward GCTTCAAGGCTACTCTGGCATTAG } \\
\text { Reverse CCTGAGGCAGTGACCGTTCC }\end{array}$ & 200 \\
\hline$T H T$ & Potato tyramine $N$-(hydroxycinnamoyl) transferase & AB061243 & $\begin{array}{l}\text { Forward TGGCTCCTGCTCCTCAAC } \\
\text { Reverse CGTTATTGTTTTCCGATGATG }\end{array}$ & 250 \\
\hline$P O X$ & Potato peroxidase (putative peroxidase) & AM231411 & $\begin{array}{l}\text { Forward CAAGGTTGTGACGGTTCCATCC } \\
\text { Reverse ACGAGCAGCAAGAGCAAGAATG }\end{array}$ & 200 \\
\hline POTLX3 & Potato locus lipoxygenase & U60202 & $\begin{array}{l}\text { Forward GCAGAAAGCCAACAAAAGCA } \\
\text { Reverse CGGGGATAAGGAACTGAACA }\end{array}$ & 250 \\
\hline EIN3 & $\begin{array}{l}\text { Potato ethylene-insensitive } 3 \text { (EIN3-binding } \\
\text { F box protein 1) }\end{array}$ & CK279984 & $\begin{array}{l}\text { Forward CGACTCTGCTGCTACCGATGG } \\
\text { Reverse GGTTCTTTCACTCTCAGGTTGCTC }\end{array}$ & 200 \\
\hline$L 2$ & Potato ribosomal protein $\mathrm{L} 2$ & CK259681.1 & $\begin{array}{l}\text { Forward GGCGAAATGGGTCGTGTTAT } \\
\text { Reverse CATTTCTCTCGCCGAAATCG }\end{array}$ & 300 \\
\hline Actin 7 & Potato actin 7 & DQ252512 & $\begin{array}{l}\text { Forward CATCCTGTCCTCCTAACTGAAGCC } \\
\text { Reverse TCACCAGAGTCCAACACAATACCG }\end{array}$ & 200 \\
\hline$G A P D H$ & Potato glyceraldehyde-3-phosphate dehydrogenase & U170005 & $\begin{array}{l}\text { Forward ACAGGTTTGGCATTGTGGAG } \\
\text { Reverse GTTTTCTGGGTGGCAGTCAT }\end{array}$ & 300 \\
\hline
\end{tabular}


Null hypotheses were rejected if $P<0.05$. Residuals normality of and variances homogeneity were verified.

Kruskal-Wallis analyses were performed with $\mathrm{R}$ software 3.3.1 for plant defense-gene expression and transcript accumulation.

\section{ACKNOWLEDGMENTS}

The authors thank R. Corbière and V. Lecomte for advice and help with strain maintenance and R. Lopes Martin for sporangia collection. The authors are grateful to the INRA Genetic Resources Center BrACySol of Ploudaniel for providing the plant material used in the tests. The authors also acknowledge N. Seal, English consultant for the manuscript corrections.

\section{LITERATURE CITED}

Bengtsson, T., Holefors, A., Witzell, J., Andreasson, E., and Liljeroth, E. 2014. Activation of defence responses to Phytophthora infestans in potato by BABA. Plant Pathol. 63:193-202.

Clément, J. 2011. Stratégies de reproduction de l'oomycète hétérothallique Phytophthora infestans en réponse aux infections multiples et à la résistance partielle de son hôte Solanum tuberosum. Université Européenne de Bretagne, Rennes, France.

Clément, J. A. J., Magalon, H., Pellé, R., Marquer, B., and Andrivon, D. 2010. Alteration of pathogenicity-linked life-history traits by resistance of its host Solanum tuberosum impacts sexual reproduction of the plant pathogenic oomycete Phytophthora infestans. J. Evol. Biol. 23: 2668-2676.

Desender, S., Klarzynski, O., Potin, P., Barzic, M.-R., Andrivon, D., and Val, F. 2006. Lipopolysaccharides of Pectobacterium atrosepticum and Pseudomonas corrugata induce different defence response patterns in tobacco, tomato, and potato. Plant Biol Stuttg 8:636-645.

Dufour, M. C., Lambert, C., Bouscaut, J., Mérillon, J. M., and Corio-Costet, M. F. 2013. Benzothiadiazole-primed defence responses and enhanced differential expression of defence genes in Vitis vinifera infected with biotrophic pathogens Erysiphe necator and Plasmopara viticola. Plant Pathol. 62:370-382.

Floryszak-Wieczorek, J., Arasimowicz-Jelonek, M., and Abramowski, D. 2015. BABA-primed defense responses to Phytophthora infestans in the next vegetative progeny of potato. Front. Plant Sci. 6:844.

Fry, W. 2008. Phytophthora infestans: The plant (and $R$ gene) destroyer. Mol. Plant Pathol. 9:385-402.

Gyetvai, G., Sønderkær, M., Göbel, U., Basekow, R., Ballvora, A., Imhoff, M., Kersten, B., Nielsen, K.-L., and Gebhardt, C. 2012. The transcriptome of compatible and incompatible interactions of potato (Solanum tuberosum) with Phytophthora infestans revealed by DeepSAGE analysis. PLoS One 7:e31526.

Haas, B. J., Kamoun, S., Zody, M. C., Jiang, R. H. Y., Handsaker, R. E., Cano, L. M., Grabherr, M., Kodira, C. D., Raffaele, S., Torto-Alalibo, T., Bozkurt, T. O., Ah-Fong, A. M., Alvarado, L., Anderson, V. L., Armstrong, M. R., Avrova, A., Baxter, L., Beynon, J., Boevink, P. C., Bollmann, S. R., Bos, J. I., Bulone, V., Cai, G., Cakir, C., Carrington, J. C., Chawner, M., Conti, L., Costanzo, S., Ewan, R., Fahlgren, N., Fischbach, M. A., Fugelstad, J., Gilroy, E. M., Gnerre, S., Green, P. J., Grenville-Briggs, L. J., Griffith, J., Grünwald, N. J., Horn, K., Horner, N. R., Hu, C. H., Huitema, E., Jeong, D. H., Jones, A. M., Jones, J. D., Jones, R. W., Karlsson, E. K., Kunjeti, S. G., Lamour, K., Liu, Z., Ma, L., Maclean, D., Chibucos, M. C., McDonald, H., McWalters, J., Meijer, H. J., Morgan, W., Morris, P. F., Munro, C. A., O'Neill, K., OspinaGiraldo, M., Pinzón, A., Pritchard, L., Ramsahoye, B., Ren, Q., Restrepo, S., Roy, S., Sadanandom, A., Savidor, A., Schornack, S., Schwartz, D. C., Schumann, U. D., Schwessinger, B., Seyer, L., Sharpe, T., Silvar, C., Song, J., Studholme, D. J., Sykes, S., Thines, M., van de Vondervoort, P. J., Phuntumart, V., Wawra, S., Weide, R., Win, J., Young,
C., Zhou, S., Fry, W., Meyers, B. C., van West, P., Ristaino, J., Govers, F., Birch, P. R., Whisson, S. C., Judelson, H. S., and Nusbaum, C. 2009. Genome sequence and analysis of the Irish potato famine pathogen Phytophthora infestans. Nature 461:393-398.

Haverkort, A. J., Struik, P. C., Visser, R. G. F., and Jacobsen, E. 2009. Applied biotechnology to combat late blight in potato caused by Phytophthora infestans. Potato Res. 52:249-264.

Kirk, W. W., Abu-El Samen, F. M., Muhinyuza, J. B., Hammerschmidt, R., Douches, D. S., Thill, C. A., Groza, H., and Thompson, A. L. 2005. Evaluation of potato late blight management utilizing host plant resistance and reduced rates and frequencies of fungicide applications. Crop Prot. 24:961-970.

Kröner, A., Hamelin, G., Andrivon, D., and Val, F. 2011. Quantitative resistance of potato to Pectobacterium atrosepticum and Phytophthora infestans: Integrating PAMP-triggered response and pathogen growth. PLoS One 6:e23331.

Kröner, A., Marnet, N., Andrivon, D., and Val, F. 2012. Nicotiflorin, rutin and chlorogenic acid: Phenylpropanoids involved differently in quantitative resistance of potato tubers to biotrophic and necrotrophic pathogens. Plant Physiol. Biochem. 57:23-31.

Lees, A. K., Sullivan, L., Lynott, J. S., and Cullen, D. W. 2012. Development of a quantitative real-time PCR assay for Phytophthora infestans and its applicability to leaf, tuber and soil samples. Plant Pathol. 61:867-876.

Liljeroth, E., Bengtsson, T., Wiik, L., and Andreasson, E. 2010. Induced resistance in potato to Phytphthora infestans-Effects of BABA in greenhouse and field tests with different potato varieties. Eur. J. Plant Pathol. 127:171-183.

Mariette, N., Mabon, R., Corbière, R., Boulard, F., Glais, I., Marquer, B., Pasco, C., Montarry, J., and Andrivon, D. 2016. Phenotypic and genotypic changes in French populations of Phytophthora infestans: Are invasive clones the most aggressive? Plant Pathol. 65:577-586.

Montarry, J., Corbiere, R., and Andrivon, D. 2007. Is there a trade-off between aggressiveness and overwinter survival in Phytophthora infestans? Funct. Ecol. 21:603-610.

Moushib, L. I., Witzell, J., Lenman, M., Liljeroth, E., and Andreasson, E. 2013. Sugar beet extract induces defence against Phytophthora infestans in potato plants. Eur. J. Plant Pathol. 136:261-271.

Nega, A. 2014. Review on concepts in biological control of plant pathogens. Biol. Agric. Healthc. 4:33-54.

Paulert, R., Talamini, V., Cassolato, J. E. F., Duarte, M. E. R., Noseda, M. D., Smania, A., and Stadnik, M. J. 2009. Effects of sulfated polysaccharide and alcoholic extracts from green seaweed Ulva fasciata on anthracnose severity and growth of common bean (Phaseolus vulgaris L.). J. Plant Dis. Prot. 116:263-270.

Saubeau, G. 2014. Implication of PAMP-triggered immunity in quantitative resistance of potato to Phytophthora infestans? Ph.D thesis. Université Européenne de Bretagne, Rennes, France (in French).

Saubeau, G., Gaillard, F., Legentil, L., Nugier-Chauvin, C., Ferrières, V., Andrivon, D., and Val, F. 2014. Identification of three elicitins and a galactan-based complex polysaccharide from a concentrated culture filtrate of Phytophthora infestans efficient against Pectobacterium atrosepticum. Molecules 19:15374-15390.

Saubeau, G., Perrin, F., Marnet, N., Andrivon, D., and Val, F. 2016. Hormone signalling pathways are differentially involved in quantitative resistance of potato to Phytophthora infestans. Plant Pathol. 65:342-352.

Vleeshouwers, V. G. A. A., Van Dooijeweert, W., Govers, F., Kamoun, S., and Colon, L. T. 2000. Does basal PR gene expression in Solanum species contribute to non-specific resistance to Phytophthora infestans? Physiol. Mol. Plant Pathol. 57:35-42.

Walters, D., Newton, A. C., and Lyon, G., eds. 2007. Induced resistance for plant defence: A sustainable approach to crop protection. Blackwell, Oxford.

Yi, M., and Valent, B. 2013. Communication between filamentous pathogens and plants at the biotrophic interface. Annu. Rev. Phytopathol. 51:587-611. 